\title{
(2) OPEN ACCESS \\ Utility of endoscopic transpapillary pancreatic cyst drainage for intraductal papillary mucinous neoplasm infection
}

\author{
Shunsuke Watanabe, ${ }^{1}$ Masao Toki, ${ }^{1}$ Junji Shibahara, ${ }^{2}$ Tadakazu Hisamatsu ${ }^{1}$
}

'Department of Gastroenterology and Hepatology, Kyorin University Hospital, Mitaka, Tokyo, Japan ${ }^{2}$ Department of Pathology, Kyorin University Hospital, Mitaka, Tokyo, Japan

Correspondence to Professor Tadakazu Hisamatsu thisamatsu@ks.kyorin-u.ac.jp

Accepted 12 May 2021

\section{Check for updates}

(C) BMJ Publishing Group Limited 2021. Re-use permitted under CC BY-NC. No commercial re-use. See rights and permissions. Published by BMJ.

To cite: Watanabe S, Toki M, Shibahara J, et al. BMJ Case Rep 2021;14:e242583. doi:10.1136/bcr-2021242583

\section{SUMMARY}

A 61-year-old woman with intraductal papillary mucinous neoplasm (IPMN) infection, who was treated with antibiotics, developed IPMN reinfection with febrile epigastric pain and was febrile. CT showed that the diameter of the IPMN had grown and hardened, with thickening of the cyst wall. Endoscopic retrograde pancreatography was then performed and a nasopancreatic cyst drainage tube was placed into the cyst. Symptoms and inflammatory findings improved considerably 17 days after endoscopic drainage. Few reports and evidence have been found regarding IPMN infections, and the frequency of onset, route of infection and optimal drainage method remain unknown. This study indicated that endoscopic transpapillary pancreatic cyst drainage was effective and is highly recommended for IPMN infection.

\section{BACKGROUND}

Advancements in cross-sectional imaging, for example, CT and MRI, have allowed frequent detection of pancreatic cystic lesions, often incidentally. ${ }^{1}$ Approximately $50 \%$ of all pancreatic cystic lesions are pancreatic cystic neoplasms (PCNs), ${ }^{2}$ among which, intraductal papillary mucinous neoplasms (IPMNs) are the most common, ${ }^{3}$ with an estimated prevalence of 26/100 $000 .{ }^{4}$ In Japan, IPMN is often treated in accordance with the International Consensus Guideline. ${ }^{5}$ Considering that IPMN produces mucin, acute pancreatitis caused by a large amount of mucin has been recognised as a major adverse event in $\operatorname{IPMN}^{67}$ along with concomitant pancreatic ductal adenocarcinoma and extrapancreatic malignancies. ${ }^{8}$ In contrast, given the limited reports on IPMN infection as an adverse event, its frequency, infection mechanism, appropriate treatment and relation of malignancy have not been clarified.

We, herein, report a case of IPMN infection that was successfully treated with endoscopic transpapillary pancreatic cyst drainage without malignant findings.

\section{CASE PRESENTATION}

A 61-year-old woman diagnosed with IPMN through magnetic resonance cholangiopancreatgraphy and endoscopic ultrasonography (EUS) 5 years prior to presentation (figure 1) was admitted to our facility with fever and epigastric pain that persisted for 2 days with her body temperature reaching $38.2^{\circ} \mathrm{C}$.
Approximately 20 months prior to presentation, the patient was treated for IPMN infection, which improved through antibiotics alone and without cyst drainage. Follow-up MRI had been continued every 6 months. Although the diameter grew slowly, no reinfection and malignant signs, such as highrisk stigmata (HRS), were observed.

When presenting at our facility, her symptoms were very similar to those of the previous IPMN infection, and we suspected IPMN reinfection.

\section{INVESTIGATIONS}

Blood tests revealed a marked inflammatory response: $23.3 \times 10^{9}$ white cell count $/ \mathrm{L}, 27.9 \mu \mathrm{g} /$ $\mathrm{mL} \mathrm{C}$ reactive protein, and $3.89 \mathrm{ng} / \mathrm{mL}$ procalcitonin. Pancreatic enzyme and all tumour markers were within the reference range (table 1). Contrastenhanced CT revealed that IPMN had grown from 34.2 to $47.2 \mathrm{~mm}$, with a hardening of the cyst, thickening of the cyst wall, and existence of a dirty fat sign around the cyst (figure 2).

\section{DIFFERENTIAL DIAGNOSIS}

Patients who present with a connection route between the main pancreatic duct (MPD) and cyst may have branch duct-type IPMN (BD-IPMN), retention cyst, and pancreatic pseudocyst caused by pancreatitis. A connection between multilocular cysts and the MPD is a typical finding in BD-IPMN. However, no findings of acute pancreatitis, such as elevated pancreatic enzymes and pancreatic swelling, were noted. Given that the inflammatory sign was localised around the cyst, IPMN infection was considered.

\section{TREATMENT}

The patient received the same antibiotics as on previous presentation, but the inflammatory

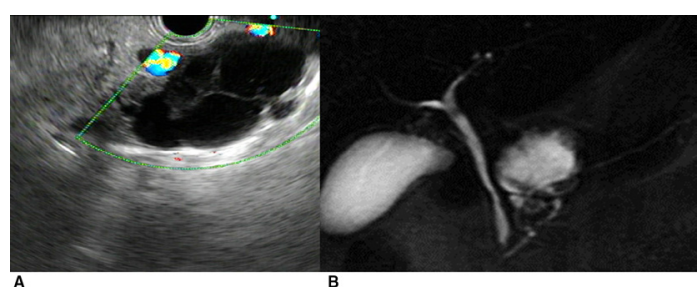

Figure 1 Endoscopic ultrasound image and MR cholangiopancreatography imaging 5 years prior to presentation. The maximum diameter of the cyst was $34.2 \mathrm{~mm}$. The pancreatic cyst was multilocular (A) and connected to the main pancreatic duct (B). 


\begin{tabular}{|c|c|c|c|c|c|}
\hline \multicolumn{3}{|c|}{$<$ Complete blood count $>$} & \multicolumn{3}{|c|}{ <Biological examination> } \\
\hline RCC & $4.58 \times 10^{12}$ & /L & $\mathrm{Na}$ & 137 & $\mathrm{mEq} / \mathrm{L}$ \\
\hline $\mathrm{Hgb}$ & 13.6 & $\mathrm{~g} / \mathrm{dL}$ & K & 3.1 & $\mathrm{mEq} / \mathrm{L}$ \\
\hline Plt & $23.8 \times 10^{4}$ & $/ \mu \mathrm{L}$ & $\mathrm{Cl}$ & 96 & $\mathrm{mEq} / \mathrm{L}$ \\
\hline \multirow[t]{2}{*}{ WCC } & $23.3 \times 10^{9}$ & $/ L$ & Alb & 4.1 & $\mathrm{~g} / \mathrm{dL}$ \\
\hline & & & BUN & 13.3 & $\mathrm{mg} / \mathrm{dL}$ \\
\hline \multicolumn{3}{|c|}{$<$ Blood coagulation test $>$} & $\mathrm{Cr}$ & 0.50 & $\mathrm{mg} / \mathrm{dL}$ \\
\hline PT & 89.0 & $\%$ & T-Bil & 3.3 & $\mathrm{mg} / \mathrm{dL}$ \\
\hline APTT & 39.5 & $\mathrm{sec}$ & D-Bil & 0.8 & $\mathrm{mg} / \mathrm{dL}$ \\
\hline FDP & 5.0 & $\mu \mathrm{g} / \mathrm{mL}$ & ALP & 222 & IU/L \\
\hline \multirow[t]{2}{*}{ D-dimer } & 0.7 & $\mu \mathrm{g} / \mathrm{mL}$ & $\gamma \mathrm{GTP}$ & 69 & IU/L \\
\hline & & & AST & 40 & IU/L \\
\hline \multicolumn{3}{|c|}{$<$ Tumour marker> } & ALT & 58 & IU/L \\
\hline CEA & 1.4 & $\mathrm{ng} / \mathrm{mL}$ & Amylase & 71 & IU/L \\
\hline CA19-9 & 19.9 & $\mathrm{U} / \mathrm{mL}$ & Lipase & 125 & IU/L \\
\hline Span-1 & 15.3 & $\mathrm{U} / \mathrm{mL}$ & CRP & 27.9 & $\mathrm{mg} / \mathrm{dL}$ \\
\hline DUPAN-2 & 25 & $\mathrm{U} / \mathrm{mL}$ & PCT & 3.89 & $\mathrm{ng} / \mathrm{mL}$ \\
\hline
\end{tabular}

Alb, Albumin; ALP, alkaline phosphatase; ALT, alanine aminotransferase; APTT, activated partial thromboplastin time; AST, aspartate aminotransferase; BUN, blood urea nitrogen; CA19-9, carbohydrate antigen; CEA, carcinoembryonic antigen; $\mathrm{Cl}$, chlorine; Cr, creatinine; CRP, C reactive protein; D-Bil, direct bilirubin; DUPAN-2, duke pancreatic monoclonal antigen type 2; FDP, fibrin and fibrinogen degradation products; $r$ GTP, $\gamma$-glutamyltransferase; Hgb, haemoglobin; $\mathrm{K}$, potassium; $\mathrm{Na}$, sodium; $\mathrm{PCT}$, procalcitonin; Plt, platelet; PT, prothrombin time; RCC, red cell count; Span-1, S-pancreas-1 antigen; T-Bil, total bilirubin; WCC, white cell count.

response had progressed further. Cyst drainage was required to control inflammation, and endoscopic transpapillary pancreatic cyst drainage was performed (figure 3). No expansion of the pancreatic duct orifice and mucus drainage in duodenal papilla was observed. The diameter of the MPD was slightly dilated to $3.4 \mathrm{~mm}$; the cyst connected with the MPD was visualised using endoscopic retrograde pancreatography. A catheter was inserted into the cyst, and a viscous yellowish-white pus was aspirated from it (figure 4). A nasocystic drainage tube (Cook Medical Japan, Tokyo, Japan) was placed into the cyst and continuous drainage was performed.

\section{OUTCOME AND FOLLOW-UP}

Follow-up contrast-enhanced CT revealed improvement in cyst hardness and cyst wall thickness, and the dirty fat sign around the cyst disappeared (figure 5). Both inflammatory response and abdominal symptoms improved 17 days after drainage, whereas the drainage tube was removed 21 days later. Klebsiella pneumoniae was detected in the pus bacterial culture, whereas negative findings were found on blood culture. Cytological examination of the cyst fluid revealed only inflammatory cells against a mucus background. Owing to the absence of neoplastic

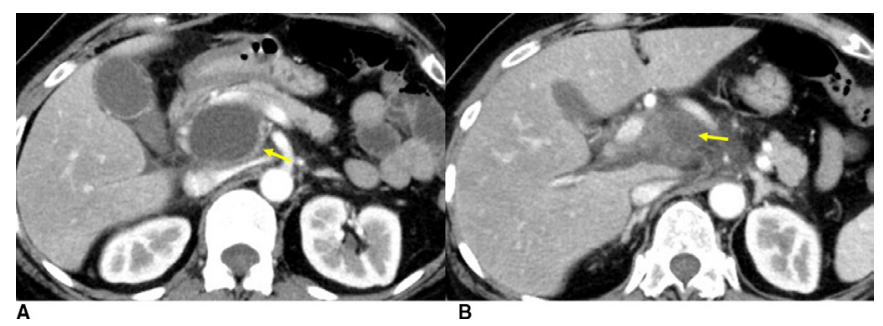

Figure 2 CT images on admission. The maximum diameter of the cyst increased to $47.2 \mathrm{~mm}$. The cyst wall thickened (A: arrow) and a dirty fat sign was again recognised around the cyst (B: arrow).

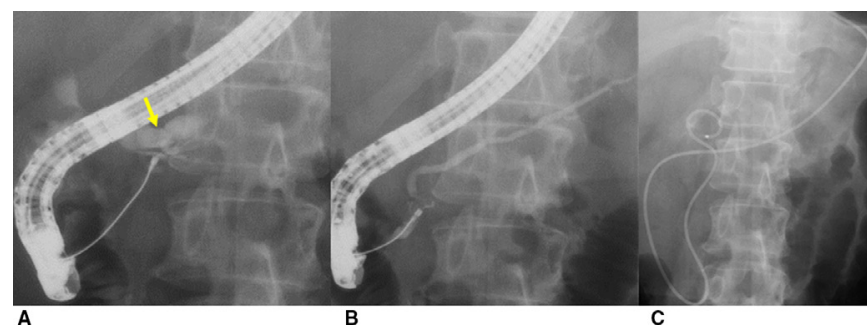

Figure 3 Endoscopic retrograde pancreatography images. The pancreatic cyst was connected to the main pancreatic duct (A: arrow). The diameter of main pancreatic duct was $3.4 \mathrm{~mm}$ (B). The catheter was placed transpapillary into the cyst (C).

cells, the patient's disease was categorised as class II (figure 6). Although the cyst did not disappear, she was discharged without an internal fistula for cyst drainage considering the improvement of the infection.

\section{DISCUSSION}

The current study highlights the utility of transpapillary pancreatic cyst drainage in the treatment of infection to prevent dissemination. Currently, pancreatic cyst drainage can be performed through not only the transpapillary approach but also transmural technique with EUS. ${ }^{9}$ However, the transmural technique with EUS is generally performed for non-PCN conditions, such as pancreatic pseudocysts and walled-off necrosis. The international consensus guidelines ${ }^{5}$ do not recommend the transmural technique with EUS for both cell sampling and drainage in patients with PCN due to the possibility of neoplastic cell dissemination. Lerch et al reported that transpapillary pancreatic cyst drainage is perhaps the least traumatic procedure for pancreatic cysts connected to the MPD. ${ }^{10}$ Watanabe et al, who investigated IPMN infection similar to the present report, ${ }^{11}$ also recommended transpapillary drainage and succeeded in placing an indwelling drainage tube into the IPMN. Despite the unclear route of infection in IPMN, some studies have suspected retrograde infection, which involves bacterial translocation of the

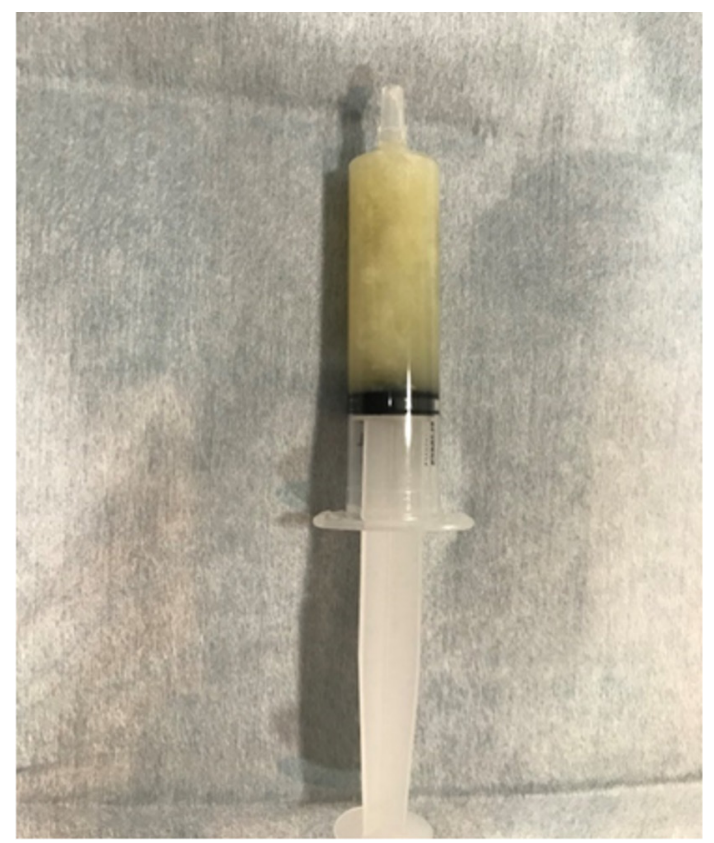

Figure 4 The drained fluid showing yellowish-white pus. 


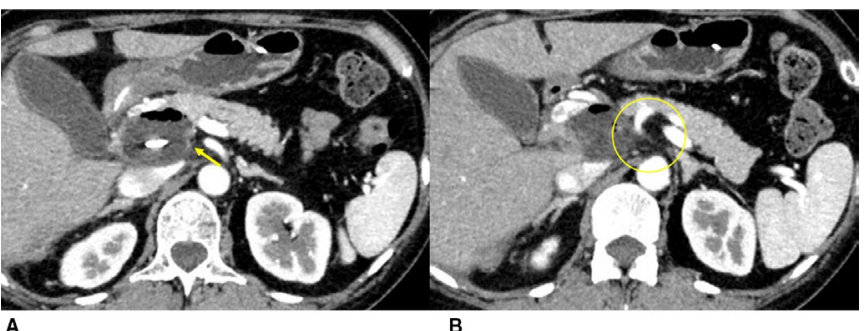

Figure $5 \mathrm{CT}$ images after the successful drainage. The cyst hardness and cyst wall thickness improved (A: arrow) and the dirty fat sign around the cyst disappeared (B: circle).

intestinal flora more commonly observed in acute pancreatitis than in transpapillary infection. ${ }^{11}$ Moreover, the cyst is thought to be directly infected without passing through the papilla. It is possible that the infection did not improve with MPD drainage only because it was not a transpapillary infection. Because no signs of obstruction were observed in the MPD of the current case, the drainage tube could be placed directly into the cyst for better drainage (instead of in the MPD), which also improved infection control.

The predictive factors of malignant IPMN have been previously identified, with several features having been associated with the presence of symptoms, such as diabetes, jaundice, tumour size and dilatation of the MPD. ${ }^{12}$ In a case report involving IPMN infection, ${ }^{11}$ in which one case was diagnosed with moderate dysplasia and another with invasive tubular adenocarcinoma using surgical specimens, surgical resection soon after drainage was strongly recommended. Because the current case was categorised as class II without neoplastic cells following cytological examination of cyst fluid and did not have HRS, we decided that the findings suggestive of malignant IPMN were poor. Even after 24 months, the IPMN did not show signs of malignancy. IPMN infection may be one of the findings of malignancy; therefore, it is necessary to carefully consider the indications for surgical resection after preoperative evaluation, including cytological

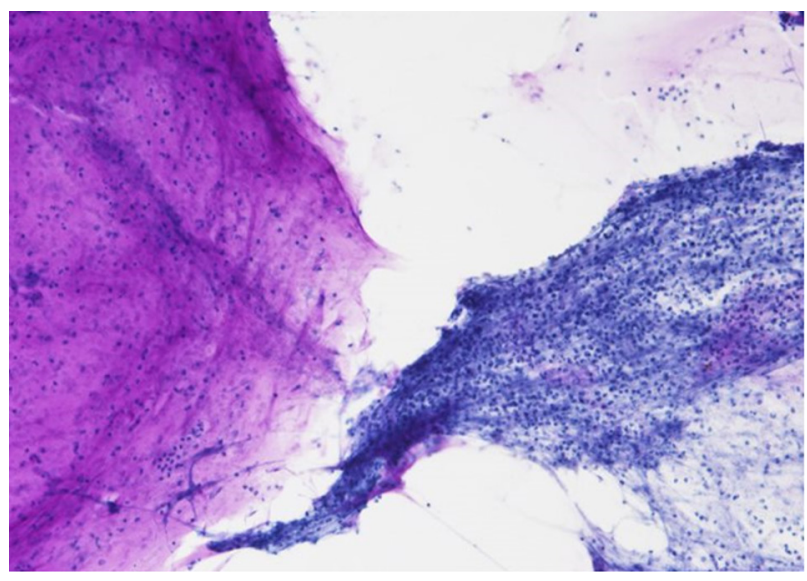

Figure 6 Cytological examination of the cyst fluid (PAS staining). Only inflammatory cells against a mucus background were observed without neoplastic cells. PAS staining, Periodic Acid Schiff staining. examination and consultation with the surgical department, and to closely follow-up the patient to identify findings suggesting malignancy.

\section{Learning points}

- Endoscopic transpapillary cyst drainage is an effective and safe method for managing intraductal papillary mucinous neoplasm (IPMN) infection with an obvious connection to the main pancreatic duct.

- IPMN infection is a rare symptom that can be caused by bacterial translocation of the intestinal flora.

- Although symptomatic IPMN is considered a risk factor for malignancy in IPMN, surgical indications should be carefully considered in IPMN infections.

Acknowledgements We thank Edanz Group (https://en-author-services.edanz. com/ac) for editing a draft of this manuscript.

Contributors SW: planning, conduct, reporting of the work, writing original draft MT: planning, conduct, manuscript review and editing. JS: planning, conduct. TH: planning, manuscript review and editing, supervision.

Funding The authors have not declared a specific grant for this research from any funding agency in the public, commercial or not-for-profit sectors.

Competing interests None declared.

Patient consent for publication Obtained.

Provenance and peer review Not commissioned; externally peer reviewed.

Open access This is an open access article distributed in accordance with the Creative Commons Attribution Non Commercial (CC BY-NC 4.0) license, which permits others to distribute, remix, adapt, build upon this work non-commercially, and license their derivative works on different terms, provided the original work is properly cited and the use is non-commercial. See: http://creativecommons.org/ licenses/by-nc/4.0/

\section{REFERENCES}

1 Lee KS, Sekhar A, Rofsky NM, et al. Prevalence of incidental pancreatic cysts in the adult population on MR imaging. Am J Gastroentero/ 2010;105:2079-84.

2 Laffan TA, Horton KM, Klein AP, et al. Prevalence of unsuspected pancreatic cysts on MDCT. AJR Am J Roentgenol 2008;191:802-7.

3 Crippa S, Arcidiacono PG, De Cobelli F, et al. Review of the diagnosis and management of intraductal papillary mucinous neoplasms. United European Gastroenterol J 2020:8:249-55.

4 Reid-Lombardo KM, St Sauver J, Li Z, et al. Incidence, prevalence, and management of intraductal papillary mucinous neoplasm in Olmsted County, Minnesota, 1984-2005: a population study. Pancreas 2008;37:139-44.

5 Tanaka M, Fernández-Del Castillo C, Kamisawa T, et al. Revisions of international consensus Fukuoka guidelines for the management of IPMN of the pancreas. Pancreatology 2017;17:738-53.

6 Ringold DA, Shroff P, Sikka SK, et al. Pancreatitis is frequent among patients with side-branch intraductal papillary mucinous neoplasia diagnosed by EUS. Gastrointest Endosc 2009:70:488-94.

7 McGrath K, Slivka A. Diagnosis and management of intraductal papillary mucinous neoplasia. Nat Clin Pract Gastroenterol Hepatol 2005;2:316-22.

8 Castellano-Megías VM, Andrés Cl-de, López-Alonso G, et al. Pathological features and diagnosis of intraductal papillary mucinous neoplasm of the pancreas. World J Gastrointest Oncol 2014;6:311-24

9 Ang TL, Teoh AYB. Endoscopic ultrasonography-guided drainage of pancreatic fluid collections. Dig Endosc 2017;29:463-71.

10 Lerch MM, Stier A, Wahnschaffe U, et al. Pancreatic pseudocysts: observation, endoscopic drainage, or resection? Dtsch Arzteb/ Int 2009;106:614-21.

11 Watanabe K, Karasaki H, Mizukami Y, et al. Cyst infection of intraductal papillary mucinous neoplasms of the pancreas: management of a rare complication: report of 2 cases. Pancreas 2014;43:478-81

12 Sugiyama M, Izumisato $\mathrm{Y}$, Abe N, et al. Predictive factors for malignancy in intraductal papillary-mucinous tumours of the pancreas. Br J Surg 2003;90:1244-9. 
Copyright 2021 BMJ Publishing Group. All rights reserved. For permission to reuse any of this content visit https://www.bmj.com/company/products-services/rights-and-licensing/permissions/

BMJ Case Report Fellows may re-use this article for personal use and teaching without any further permission.

Become a Fellow of BMJ Case Reports today and you can:

- Submit as many cases as you like

- Enjoy fast sympathetic peer review and rapid publication of accepted articles

Access all the published articles

Re-use any of the published material for personal use and teaching without further permission

Customer Service

If you have any further queries about your subscription, please contact our customer services team on +44 (0) 2071111105 or via email at support@bmj.com.

Visit casereports.bmj.com for more articles like this and to become a Fellow 